\title{
SUSTAINABLE PRODUCTION AND CONSUMPTION
}

\section{Andrea Keszi Szeremlei* ${ }^{*}$, Róbert Magda}

College of Dunaújváros, Szent István University, Hungary

The idea that builds on the recognition that the Earth is a finite world, the resources are not endless, and thus the vision of continuous growth cannot be sustained can be traced back to the 1960s. Global problems had already occurred by then, and trends calculated from the data indicated a rapid disaster for the future. Humanity is at crossroads, and even the directions are still unclear. In the mid-1980s, an increasingly ecological approach appeared in politics, development policy, and international institutions.

Keywords: sustainability, natural capital, sustainable economy

\section{Introduction}

Ecological thinking was fundamentally influenced by Rachel Carson's 1962 book "Silent Spring" which called attention to the polluting effects of chemical agents in a dramatic way. The American writer drew the world's attention to the importance of environment protection, and afterwards such problems had to be taken seriously.

The problems of the environment were first dealt with at the international level in Stockholm at the international conference of the "United Nations Conference on the Human Environment". The environmental impact of economic growth was carefully studied. The rich and poor countries saw the problems differently; the developed world held that the state of the environment was independent of the socio-economic conditions, while the developing nations believed that poverty is a result of the deteriorating environment.

Economists, scientists, industrialists and public figures founded the Club of Rome in 1968. In 1972, the organization published the study "The Limits to Growth" by Dennis L. Meadows in which the authors illustrate possible versions of the future by means of a model (World 3). The authors then believed that by the unity of mankind, harmful consequences could be avoided. (Heltai L., 2006)

The idea of sustainability was to a large extent spread by the United Nations World Commission on Environment and Development which started working in 1983.

Under the leadership of Norwegian Prime Minister Gro Harlem Brundtland, the commission worked out a detailed political plan on sustainable development. The Final Report was published in 1987 with the title of "Our Common Future". The report dealt with energy consumption as a central problem.

The Commission's report had two main messages:

$\square$ poverty is the cause of the unsustainable world because the poor use their environment excessively,

$\square$ economic growth is necessary for the benefit of the poor so that there are resources available to compensate for social and environmental problems.

Economic growth, however, means that more goods and services have to be created from less material and energy. The shortcoming of the report is that it does not specify that the growth potentials depend on the carrying capacity of the environment.

\section{Discussion}

\section{Scarcity}

One of the most important problems connected with the natural resources is the scarcity. Some of our resources have a limited quantity, and it is our duty to solve the problem. Physical measures of scarcity rely on looking at geological estimates of reserves, and relating this in some way to the level of demand. A very simple indicator, for example, is to divide an estimate of resources by the current level of consumption to give a period of years to exhaustion. If a demand is expected to rise, this can be built to the indicator. For example, if consumption now is $C_{0}$ (in physical units such as tonnes) and annual growth of demand is at $k$ per cent and the stock of resource is $S$, than the number of years to total exhaustion $\left(T_{E}\right)$ is given by the solution of:

$$
\int_{0}^{I_{E}} C_{0} e^{k t}=S
$$

where:

$T_{E} \quad$ - something known as the exponential index and it was made particularly famous in the publication Limits of Growth (Meadows et al., 1972)

How can we calculate it?

If the current extraction rate is 10 units $\left(C_{0}=10\right)$, the demand is growing at 10 per cent annually $(k=0.1)$ and there is a stock of 1,000 units $(S=1,000)$, we have:

$$
10 \int_{0}^{T_{E}} e^{0.1 t}=1,000
$$

Solving for a definite integral gives:

$$
\left[\begin{array}{c}
T_{E} \\
0.1 e^{0.1 t}
\end{array}\right]=\frac{1,000}{10}=100
$$

Hence:

$$
\begin{gathered}
e^{0.1 T_{E}}-e^{0}=100 \times 0.1=10 \\
e^{0}=1, \text { so that } \\
e^{0.1 T_{E}}=11
\end{gathered}
$$

Inspection of tables for the value of $e^{x}=11$ when $x=2.398$. 
Therefore:

$$
\begin{gathered}
0.1 T_{E}=2.398 \\
T_{E}=23.98
\end{gathered}
$$

It means that in less than 24 years the resource will be exhausted. In Limits to Growth, sustainable development was calculated for exhaustible resources. This methodology could be the basis, but we will have to calculate new discoveries for example from the depth of the seas and oceans.

\section{Sustainability}

The term "sustainability" appeared in the literature at the beginning of the 1980s. Lester R. Brown published his work "Building a Sustainable Society" in 1981. In a sustainable society, according to him, harmony must exist among population growth, the financial needs of society, the utilisation of natural resources and the minimization of pollution.

The United Nations World Commission on Environment and Development (WCED) defines Sustainable Development as follows: "Development that meets the needs of the present without compromising the ability of future generations to meet their own needs" (Marselek, 2012).

Gyulai (2008) explains that: "Herman Daly reveals the essence of development in the simplest way. He defines growth as an increase in size while development means to become better. Growth means to become bigger, development to become better.

Costanza (1989) created a definition from an ecological point of view. In his opinion, a condition is sustainable when the minimum

\begin{tabular}{|c|c|}
\hline Weak sustainability - (neo-classical economic approach) & Strong sustainability - (ecological economics approach) \\
\hline $\begin{array}{l}\text { the focus is on the marginal cost analysis as the system } \\
\text { necessary for decision-making - the significance of absolute } \\
\text { measure is small }\end{array}$ & $\square$ the focus is on the level of matter-energy throughput \\
\hline $\begin{array}{l}\text { the financial analysis of changes in natural capital is } \\
\text { significant }\end{array}$ & $\square$ financial analysis is negligible \\
\hline $\begin{array}{l}\square \text { discounting and the current values are central to the } \\
\text { assessment; it focuses on efficient resource allocation } \\
\text { between periods }\end{array}$ & $\begin{array}{l}\text { discounting is generally discouraged; focus is on resource } \\
\text { allocation between correct periods and the rights of future } \\
\text { generations }\end{array}$ \\
\hline$\square$ the prices are the decisive signals of relative rarity & $\begin{array}{l}\text { prices are unreliable because of the multitude of } \\
\text { externalities }\end{array}$ \\
\hline $\begin{array}{l}\text { technological progress is seen as the main factor of } \\
\text { periodically acceptable growth }\end{array}$ & $\begin{array}{l}\text { technological progress is not seen as a cure for everything, } \\
\text { rather as a factor that carries and causes environmental } \\
\text { problems }\end{array}$ \\
\hline$\square$ utilitarian approach to values & $\square$ the approach to values is based on rights \\
\hline $\begin{array}{l}\square \text { the present generation ensures sustainability by } \\
\text { retransferring the same entire capital stock }\end{array}$ & $\begin{array}{l}\text { the present generation must preserve the natural capital } \\
\text { stock for the future }\end{array}$ \\
\hline $\begin{array}{l}\text { the economists focus on the steady state when analysing } \\
\text { dynamic behaviour and natural resources management }\end{array}$ & $\begin{array}{l}\square \text { the focus is on threshold effects, uncertainty, irreversibility, } \\
\text { and flexibility }\end{array}$ \\
\hline
\end{tabular}

Table 1 Comparison of weak and strong sustainability Source: Szlávik, 2007; Hanley, Shogen and White, 2007 conditions are provided for ecosystems so that they are stable and resilient. Sustainability is a relation between human economic systems and a more dynamic but normally slower changing ecological system in which:

1. the survival of human life is provided in the long run,

2. the individual has the possibility to ensure their own and their family's well-being,

3. human societies and cultures are able to improve, but in which the effects of human activity are curbed so as not to destroy diversity, complexity, and ecological lifesupport functions"

Another example of ecocentric definition originates from the $O E C D$, according to which: Sustainable development is a development

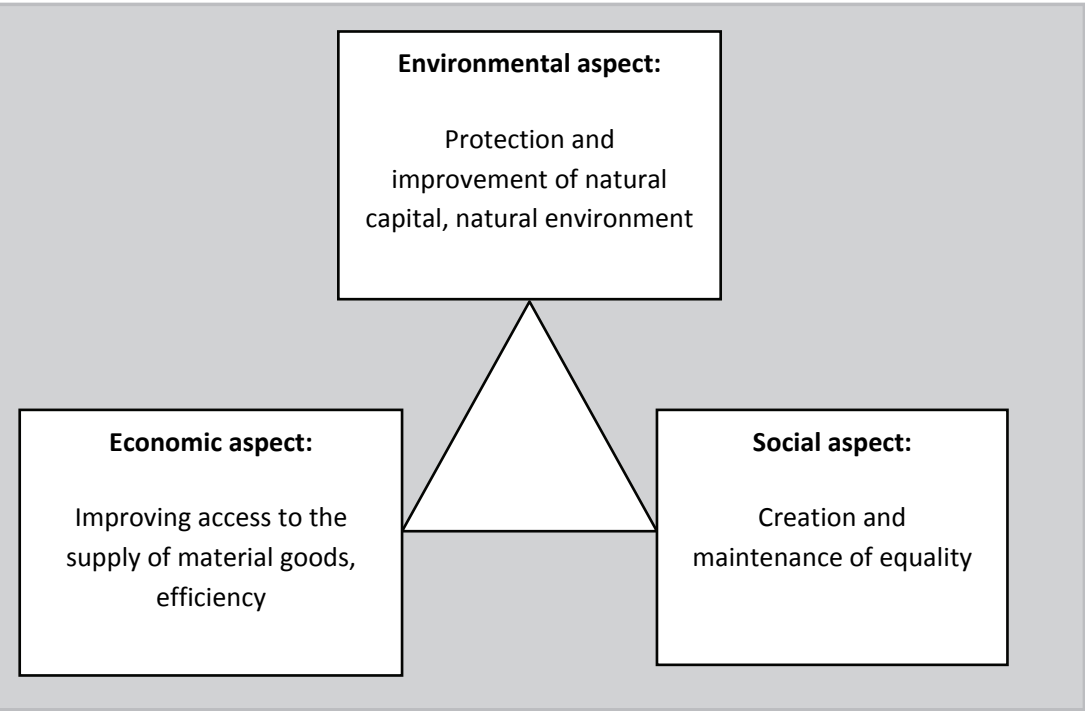

Figure 1 Aspects of sustainability Source: Abayné and Marselek, 2005 that does not harm health of populations and ecosystems, and satisfy the socio-economic needs in a way that renewable resources utilised slower than the amount of time needed for their regeneration and non-renewables are used slower than the regeneration of renewable sources that can be applied to substitute them (Csanády and Kovács, 2003; Kelemen, 2013).

Nowadays, the principle of sustainable development has two interpretations (weak and strong). Weak sustainability means that social, economic and environmental considerations are equally taken into consideration in the decisionmaking process. This is shown in Figure 1.

The weak sustainability criterion states that the total value of natural capital, human capital and that of the man-made goods as capital cannot reduce over time. This idea assumes the unlimited mutual substitutability of capital goods and creates the necessity to financially assess nature which is reflected by the applied tools (e.g. the internalization of externalities). The shortcoming of the theory is that it does not count with the unattainability of the changes caused in the ecosystem (Málovics, 2007).

In the case of strong sustainability, the external environmental constraints must be abided by as such, which means that the emissions must not exceed the environment's capacity to absorb, the use of renewable resources must not exceed the rate of formation, and the use of non-renewable resources must not exceed the rate at which sustainable and renewable substitution occurs.

Sustainability concepts may be approached from an environmental-economic and an 
ecological-economic point of view. The two directions can be interpreted as two paradigms with different conclusions (Málovics and Bajmóczy, 2009). The differences are shown in Table 1.

Sustainable development strategy is a long-term program for humanity. However, beside a global level implementation, there are national, local and micro-regional ones as well. Local levels have a crucial role in realising the objectives.

From the point of view of efficiency, it is very important to distinguish the levels and areas of sustainability (Csete, 2005). Global and long-term principles of sustainable development often unfold in the regional and local programmes, which may be organized, regulated and controlled by the authorities of a given level. At this level, they are possible to mobilize, persuade and teach people to be responsive to sustainable development (Marselek, 2005).

\section{Sustainable production and consumption}

Sustainability comprises of production and utilization that are sustainable from environmental, social and economic aspects as well as of the highest level of energy efficiency that current technology allows.

To this end, along each of the pillars of sustainability, the conditions set out in Table 2 must be satisfied in the process of production and utilisation.

Láng (2003) believes that sustainable development is based on three pillars. The Stockholm Conference created the natural environmental pillar, the Rio Conference brought the economic pillar to the forefront, while the Johannesburg Conference emphasized the social pillar.

The problems of sustainable development are system-based. Answers to local challenges cannot be provided without the knowledge of the wider context of global processes.

The changes can only be durable only if sustainable economy is realized. Sustainable economy is able to mobilize new resources, thus it is possible to expand the resources. Within a society, state must meet and secure the actual needs of its people. "The Earth can satisfy everyone's needs, but cannot satisfy everyone's greed." Today, there is enough food for all the inhabitants of the world; everyone would have enough if distribution was equal. Nevertheless, 900 million people suffer from hunger every day and 2 billion people suffer from chronic malnutrition. Every year, 18 million people die from hungerrelated illnesses (Magda, 2013).

It can be stated with confidence that if pollution reaches serious levels through the course of production and consumption, it will have a direct negative impact on the production conditions (costs) and also on the level of consumption (diminishing welfare). Therefore, for its own interest, a state is to accomplish economic regulations that help to create sustainable system of relations between mankind and nature as well as between economy and the environment.

Wackernagel and Rees (2001) report that: The analysis of the ecological footprint is a calculation tool that allows the estimation of the resource consumption and waste processing needs of a defined human population or economy measured in fertile land space.

Every human being and society occupies some space on the surface of the Earth by creating the necessary goods to sustain life, and by having the nature process wastes that are released. The size of this area is measured by the ecological footprint. It is appropriate to compare the ecological footprint with the biological capacity (available land). The difference between the biological capacity and the ecological footprint is the ecological deficit, which explains to what extent our activities are passed on to future generations. The factors affecting sustainability are shown in Figure 2. (Gebhardt B., 2006)

Gebhardt (2006) integrated into a model the relevant factors which, on the basis of his studies in Germany, have a considerable impact on sustainable consumption. According to the model, four factor groups are significant (Figure 2).

1. External factors: the place of purchase of organic food, popular ecoproducts.

2. Financial factors: income, the share of purchased organic food, their perceived premium price.

3. Cognitive and individual factors: motivations for selecting eco-products, risk sensitivity, health awareness in food purchase decisions, as well as awareness and confidence in the authenticity of the product.

4. Social impacts: the influence of opinion leaders, the effect of the immediate environment, the protection of children by means of organic food.

Table 2 Conditions for sustainable production and consumption

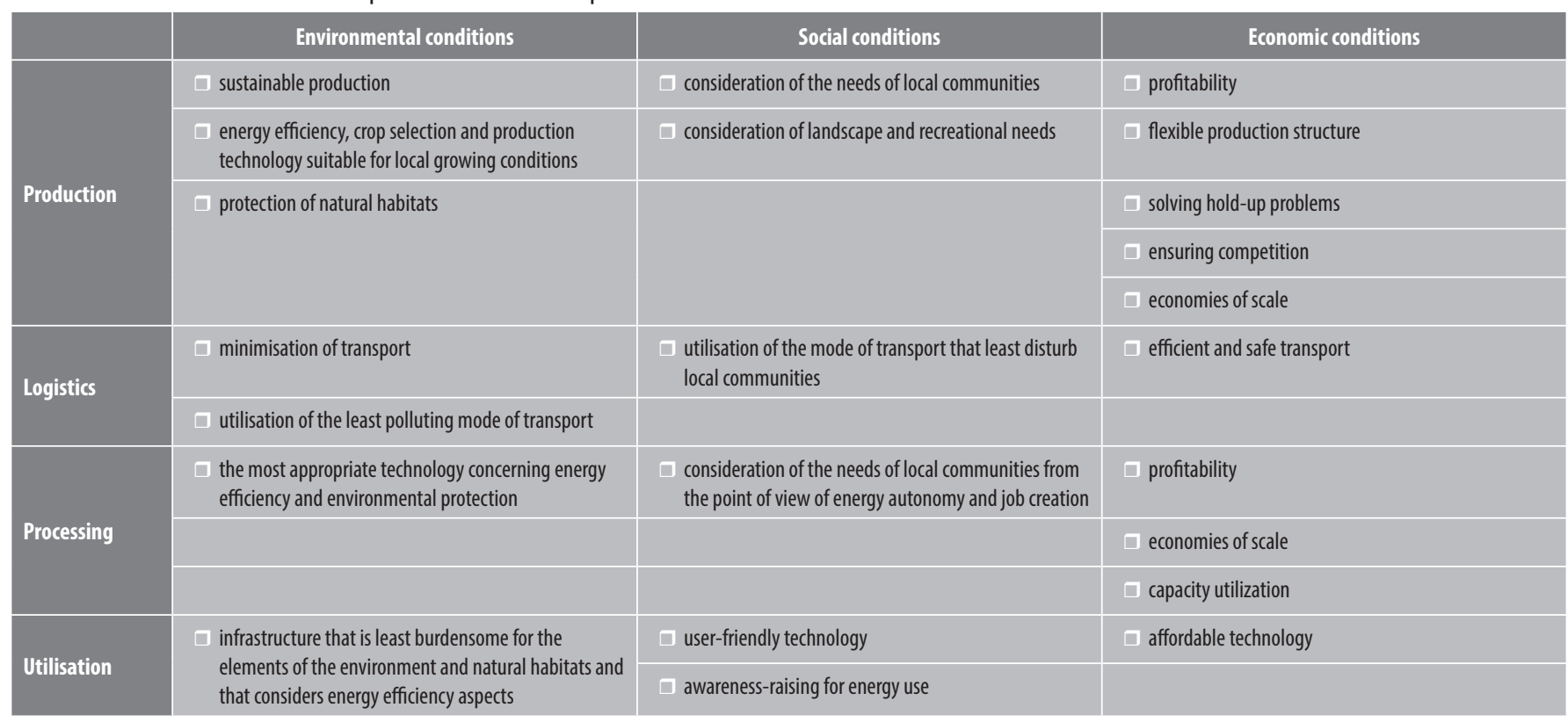

Source: Ministry of Environment and Water, 2007 


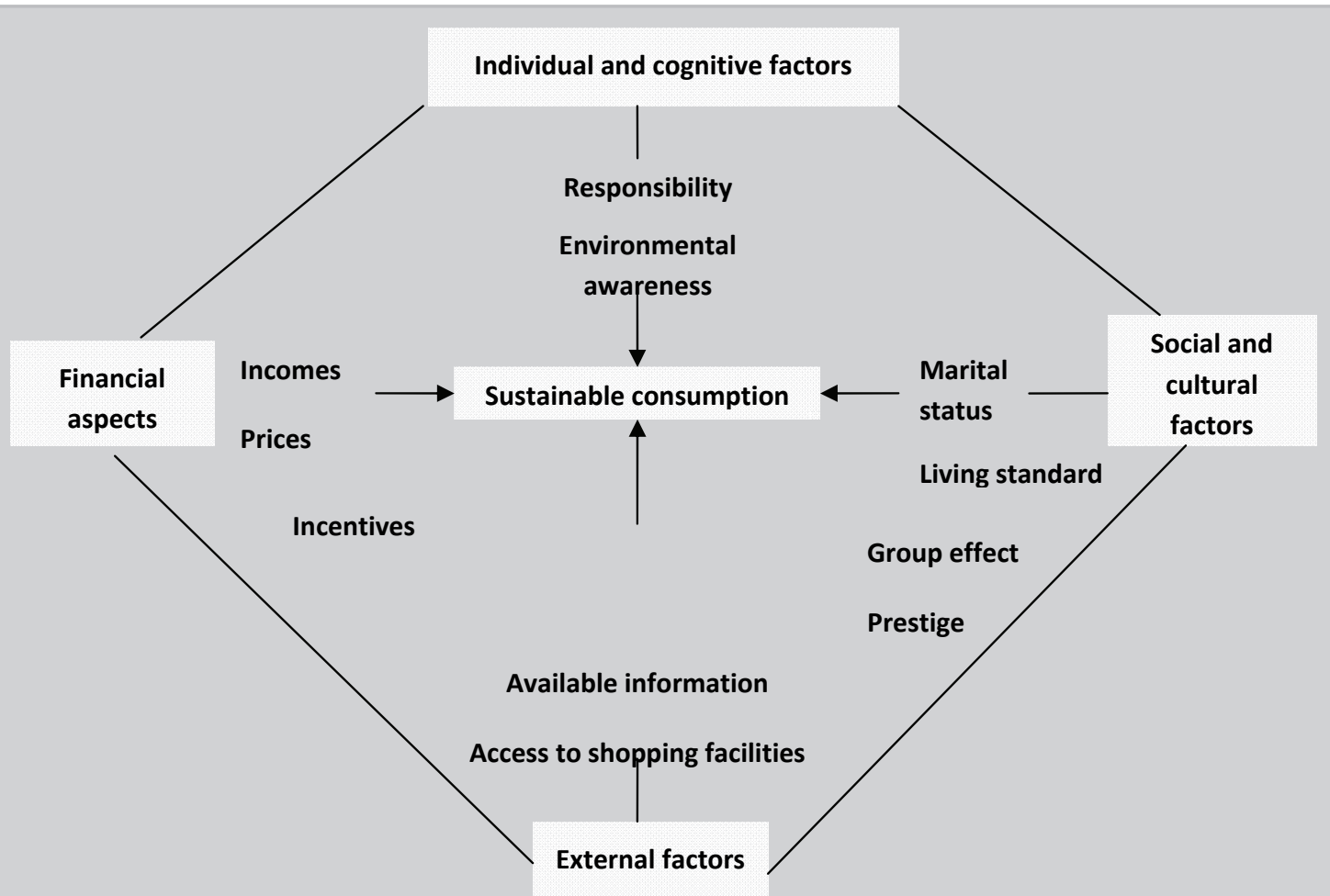

Figure 2 Factors influencing sustainable consumption and behaviour Source: Gebhardt, 2006

The need for a new paradigm of development was recognized in the mid-1980s. The UN declared the second and the third decades of development a failure because they had proved to be unable to break the cycle of poverty which evolved in the worst and poorest developing countries of the world.

Today, the situation in this respect is very bad. The balance would require a 1.5 Earths and the size of the land that indicates unsustainability is growing rapidly (with the current rate of development, 2.4 Earths are expected to be needed by 2050). Consumer could help the situation by making choices in a conscious way, but environmental awareness is still very weak.

One of the lessons of the energy crisis of the early 1970s is that the traditional, mostly fossil fuels are scarce and limited, thus their use requires extremely high level of rationality. We must strive to become familiar with the new and renewable sources of energy and their use, and also to continuously improve the balance of foreign trade. The proper management of energy sources and increased energy efficiency are particularly important in connection with competition. International competitiveness of a country means - among other things - how the available resources and assets are managed amid global competition. (Bozsik N., 2004)

The majority of people are not aware of how fast we consume natural resources. Waste is produced much faster than we could recycle it.

Our world is currently using far more resources than what sustainability would allow. Consequently, the current economic system can work only with significant additional resources. If these resources become exhausted, the economy could be seriously jeopardised. As much as $87 \%$ of resource consumption is based on fossil fuels, so their decrease represents the greatest risk. One of the great challenges of our time in all countries of the world including Hungary - is how to substitute these energy sources so that the environment is damaged to the least possible extent, and thus sustainability is ensured.

The criticism of the dominant traditional development paradigm has become universal: in all areas of development and in all disciplines.
What principles should be taken into account to achieve the changes? The main ideas are as follows:

$\square$ Responses to local challenges cannot be formulated without knowledge on the wider environment and on the global trends.

$\square$ Sustainable development integrates every aspect of the environment, economy and society.

$\square$ Sustainable development is nothing more than the sustainable management of resources, which leaves resources for future development.

$\square$ The principle of precaution (e.g. genetic engineering) must be respected.

$\square$ Previous production practices should not be forgotten so that we can get back to our roots.

$\square$ Local resources are to be utilized.

$\square$ Diversity is to be maintained (e.g. biodiversity).

$\square$ Non-material values are to be preserved. Drinking water, clean air, cultural landscape, and the pollution-free environment are all necessary for our existence while their values cannot be expressed in financial terms.

$\square$ Natural resources are to be used and preserved at the same time.

$\square$ Decisions are to be made at the local level.

$\square$ Sustainable development should become a varied system made up of small elements of organizational and economic units. The economy consists of small economic units linked to individuals and communities. The organisation made up of many micro-organisms can function as a macro-system.

\section{Summary}

The previously existing harmony between mankind and nature has ceased to exist, the Earth's resources are finite, and the exponential growth presents a deadly threat to our planet's wildlife. In countries with growing populations, the severe lack of water and food can lead to the total destruction of the social order. The population of metropolises has increased tenfold over the past forty years, in 2013 there were 23 cities whose population exceeded 10 million. The 
excessive consumption of freshwater and soil erosion make the possibility of a further rapid increase in food production dubious.

By the use of fossil fuels, 90 million tons of pollutants a day is emitted into the thin layer of the planet's atmosphere, which acts as a heat trap and accelerates global warming. In order to be able to combat the climate crisis, humanity should take immediate, significant, and coordinated actions, but it has not happened yet.

Should these processes remain unchanged, a significant extinction of species may occur, solely triggered by human activities. If we do not want to ruin the future of our children and grandchildren, any new era of economic growth must be less energy-intensive.

The globalization of economy was followed by the globalization of environmental problems, and thus no national issues exist today. This means that international cooperation is vital. National Environmental Action Plans define our country's environmental vision for the future in the interaction with the four basic resources (human, social, natural and economic).

In the current situation, the preservation of biodiversity is an essential task of mankind. Biodiversity is the basis of our existence since it provides essential ecosystem services for human life; it provides the ecological foundations for healthy food, clean fresh water, and clean air.

\section{References}

ABAYNÉ HAMAR, E. - MARSELEK, S. 2005. A fenntartható fejlődés lehetőségei. In Erdei Ferenc III. Tudományos Konferencia, Kecskemét, 2005, pp. 378-383.

BOZSIK, N. 2004. Research of the competitiveness of the Hungarian agricultural products. In Hung. Gazdálkodás, no. 9, különkiadás, 2004, pp. 21-34.

COSTANZA, R. 1989. What is Ecological Economics? In Ecological Economics, vol. 1, 1989, no. 1, pp. 1-7.

CSANÁDY, R. A. - KOVÁCS, E. 2003. A biológiai sokféleség ösztönzése és közgazdasági értékelése. Útmutató döntéshozók számára. Szemelvények az OECD Környezetpolitikájából, KvVM, Budapest, 2003.

CSETE, L. 2005. Az agrár- és vidékfejlesztés fenntartható rendszere. In Gazdálkodás, 2005, no. 2, pp. 3-16.

GEBHARDT, B. 2006. Ökokaufhaus. Konzept der Zukunft, OekomVerlag, München, 2006, pp. 16-42.

GRO HARLEM BRUNDTLAND. 1988. Közös jövőnk. A Környezet és Fejlesztés Világbizottság jelentése. Budapest : Mezőgazdasági Kiadó, 1988, pp. 1-404.
GYULAI, I. 2008. Kérdések és válaszok a fenntartható fejlődésról. Budapest : Magyar Természetvédők Szövetsége, 2008, pp. 1-56.

HANLEY - SHOGEN - WHITE. 2007. Environmental Economics. In: Theory and Practice. Second edition. Palgrave Macmillan, p. 19.

HELTAI, L. 2006. Fenntartható fejlődés. In Világgazdaság (szerk.. Andor L.) Pannonica Kiadó, Budapest, 2006, pp. 223-251.

KELEMEN, E. 2013. Az ökoszisztéma szolgáltatások közösségi részvételen alapuló, ökológiai közgazdaságtani értékelése. PhD értekezés, Szent István Egyetem, Gödöllő, 2013, pp. 1-198.

KÖRNYEZETVÉDELMI ÉS VÍZÜGYI MINISZTÉRIUM. 2007. Klímapolitika, a biomassza energetikai alkalmazásának jövője, aktuális problémái. Budapest, 2007, pp. 1-133.

LÁNG, I. 2003. A fenntartható fejlódés Johannesburg után. In Agroinform GROINFORM Kiadóház, 2003, pp. 1-147.

MAGDA, R. 2013. Fenntartható természeti környezet, hazai potenciálok. In Legjobb gyakorlatokkal a zöld gazdaságért. (szerk.: Lukács Gergely S.) CSER Könyvkiadó és Kereskedelemi Kft., Budapest, 2013, pp. 123-139.

MÁLOVICS, Gy. 2007. Fenntartható növekedés? a megújult lisszaboni stratégia kritikai elemzése a fenntarthatóság szempontjából. In Farkas Beáta (szerk.): A lisszaboni folyamat és Magyarország. SZTE Gazdaságtudományi Kar Közleményei, Szeged : JATEPress, 2007. pp. 217-232.

MÁLOVICS, Gy. - BAJMÓCZY, Z. 2009. A fenntarthatóság közgazdasági értelmezése. In Közgazdasági szemle, vol. 56, 2009, évf. május, pp. 464-483.

MARSELEK, S. 2005. Az észak-magyarországi régió fenntartható fejlődésének lehetőségei. In "Agrárgazdaság, Vidékfejlesztés, Agrárinformatika" Nemzetközi Konferencia, Debrecen (CD lemezen), 2005.

MARSELEK, S. 2012. Környezetbarát rendszerek. Kutatási terv, Károly Róbert Fôiskola, Gyöngyös, 2012, pp. 1-20.

MEADOWS, D. et al. 1972. The Limits to Growth.

SZLÁVIK, J. (szerk.). 2007. Környezet-gazdaságtan. Budapest : TYPOTEX Kiadó, 2007, pp. 1-260.

WACKERNAGEL, M. - REES, W. E. 2001. Ökológiai lábnyomunk. Föld napja Alapítvány, Budapest, 2001, pp. 1-217.

\section{Contact addresses}

Andrea Keszi Szeremlei Phd, College Professor, Institute of Social Sciences, College of Dunaújváros, Táncsics M. u. 1/A H-2401, Hungary e-mail: keszi-szeremlei.andrea@mail.duf.hu 